\title{
A Flexible Solid State EDLC From a Commercially Prepared Multiwalled Carbon Nanotubes and Hybrid Polymer Electrolytes
}

\author{
M. A. Hashim ${ }^{1} \&$ Lawal Sa' adu ${ }^{1}$ \\ ${ }^{1}$ Faculty of Science and Technology, Universiti Sains Islam Malaysia (USIM), Malaysia \\ Correspondence: Lawal Sa'adu, Faculty of Science and Technology, Universiti Sains Islam Malaysia (USIM), \\ Bandar Baru Nilai, Negeri Sembilan 71800, Malaysia. E-mail: lawals2004@gmail.com
}

\author{
Received: August 1, 2014 Accepted: August 10, 2014 Online Published: August 12, 2014 \\ doi:10.5539/jmsr.v3n4p13 URL: http://dx.doi.org/10.5539/jmsr.v3n4p13
}

\begin{abstract}
An electrochemical symmetric capacitor with a modest energy and power densities has been fabricated using a commercially prepared carbon nanotubes as electrode and hybrid solid polymer electrolyte. This integrated separator and electrolyte layer is made up of a filter paper, a polyvinyl alcohol (PVA) doped with phosphoric acid at three different concentrations. The electrode material consisted of $90 \%$ of the said carbon nanotubes and $10 \%$ of Poly (Vinylidene Fluoride-Co-Hexafluoropropylene) (PVdF-HFP). Three cells were then assembled as follows; cell-A (N90PVdF-HFP10 |H50| N90PVdF-HFP10), cell-B (N90PVdF-HFP10 |H60| N90PVdF-HFP10) and cell-C (N90PVdF-HFP10 |H70| N90PVdF-HFP10). These as-assembled symmetric supercapacitor with an optimal mass ratio was able to be operated reversibly over a wide voltage range of $0.0-3.0 \mathrm{~V}$, depending on the cell-type. Overall, the supercapacitor fabricated from cell A exhibits excellent rate capability with a capacitance, energy and power densities of $163.66 \mathrm{Fg}^{-1}, 822.00 \mathrm{Jg}^{-1}$ and $5.38 \mathrm{Jg}^{-1} \mathrm{~s}^{-1}$ respectively, and long-term cycling stability of 5000 cycles.
\end{abstract}

Keywords: multiwalled carbon nanotubes, Differential Scanning Calorimetry (DSC) Analysis, Cyclic Voltammetry (CV), Charge Discharge (CD), Hybrid Solid Polymer Electrolyte (HSPE)

\section{Introduction}

The disproportionate usage of fossil fuels in order to earn a living and meet energy requirements has grossly affected the globe, causing climatic change due to the dramatic increase in the $\mathrm{CO}_{2}$ emission (i.e. Global warming). Hence, in order to decrease our current dependence on environmentally harmful fossil fuels, the society has to move toward pursuing sustainable and renewable resources. At the moment, researchers and academia have focused their watch lights on renewable energy production from solar energy and wind energy, even though, these natural energies are subject to the climatic conditions. So, it is very imperative to devise a means of storing electricity when it is available and retrieving it when needed (Li \& Wei, 2013).

Electrochemical energy storage systems are considered to be one of the environmentally friendly alternative energy and power sources. Among them, Supercapacitors are good example of such electrochemical energy storage systems which have higher power densities (Dubal \& Rudolf, 2013) than batteries, fast charging and discharging rates, long cycle life, (Stepniak \& Ciszewski, 2010). Hence, they are commercially used in electronic markets, (Bittner et al., 2012; Wu et al., 2012), hybrid electric vehicles, (Shi et al., 2013) and other number of applications.

Although conducting polymers and transition metal oxide provide higher specific capacitance than electrochemical double layer capacitors (EDLCs), their poor rate capability, high cost and low conductivity, their academic and industrial usages become limited. The excellent chemical and physical properties of carbon materials such as high conductivity, relatively low cost, high surface area, excellent temperature stability, and good corrosion resistance make them valuable candidates for the electrodes of EDLCs, which holds true especially, for graphene and carbon nanotubes (CNTs), which possess the largest theoretical and experimental surface area (Wang et al., 2013 (a)). In view of the above, therefore, this work is aimed at presenting a flexible solid state EDLC using CNTs as an electrode material and hybrid polymer electrolytes serving as a separator and electrolyte. 


\section{Methodology}

\subsection{Electrolytic Materials}

The main electrolytic materials used here are; the $\mathrm{H}_{3} \mathrm{PO}_{4}$, PVA and Whatman filter paper. $\mathrm{The}_{3} \mathrm{H}_{3} \mathrm{PO}_{4}(>85$ wt. \% in water, molar mass of $98.00 \mathrm{gmol}^{-1}$, product, number of 1502-80) was purchased in aqueous form from R \& M marketing, Essex, UK brand, while the PVA (molecular weight; 89,000-98,000, $99+\%$ hydrolyzed) was purchased from Sigma Aldrich. Both $\mathrm{H}_{3} \mathrm{PO}_{4}$ and the powdered PVA were directly used as-received without further treatment or purification. An aqueous solution of PVA was then prepared by mixing the PVA with distilled water in the ratio of approximately $1: 10$ by volume. This solution is mechanically agitated by magnetic stirring at $60{ }^{\circ} \mathrm{C}$ for five hours to thoroughly dissolve the PVA in the distilled water. $\mathrm{H}_{3} \mathrm{PO}_{4}$ was then mixed with the PVA aqueous solution in the ratio of 70:30, 60:40 and 50:50 wt. \%.

The choice of the aforementioned percentage weights was borne out of assurance that, their respective conductivities are quite promising even at room temperature. We have since reported this development severally in (Hashim et al., 2012; Hashim et al., 2014; Sa'adu et al. (a), 2014; Sa'adu et al. (b), 2014) for a hybrid polymer electrolytes at a concentration combinational ratio of $70: 30 \mathrm{wt}$. \%. After the mixture cools down to a room temperature, the resulting homogenous solution of $\mathrm{PVA} / \mathrm{H}_{3} \mathrm{PO}_{4}$ was cast over a plastic Petri dish. This was performed, after a cellulose filter paper (Whatman brand) was cut into a $6 \mathrm{~cm} \times 5.5 \mathrm{~cm}$ (to a size that fit into the Petri dish) and soaked into the segment of the said solution. The period between the casting of the samples on the Petri dish and its drying took about 28 days.

\subsection{Electrode Materials and Cell Assembly}

The powdered MWCNTs with the following specifications; content of $0.71 \mathrm{wt} . \%$, an outer diameter of $>50 \mathrm{~nm}$,

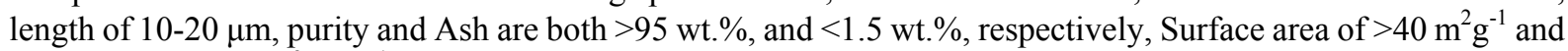
Conductivity of $>10^{2} \mathrm{Scm}^{-1}$ was obtained locally from Malaysian market (with material code SM 2/2/102). The binder used was P(VdF-HFP) (average molecular weight of $\sim 400,000$; Mn of $\sim 130,000$ pellets; product number of 427160) was purchased from Sigma Aldrich. Being a co-polymer which possesses dual properties of amorphous domains (HFP), capable of trapping large amounts of liquid electrolytes, and crystalline regions (VdF), can provide chemical stability and sufficient mechanical integrity for the processing (Lim et al., 2012). Furthermore, its electrochemical stability and performance, processability, and safety make them very unique, and to be used as a binder for fabrication of cells.

The cells for double layer capacitor were fabricated from a mixture of $90 \mathrm{wt} . \%$ of a commercially prepared multiwalled carbon nanotubes (CPNMWCNTs) and $10 \mathrm{wt} . \%$ of P(VdF-HFP), mixed inside a $20 \mathrm{ml}$ of the acetone. The resulting slurry was cast onto to the Aluminum foil and was allowed to dry for about two hours at room temperature. Prior to that, an applicator was used to smooth the poured slurry with the view to leveling it and obtaining a desired thickness which was around $0.127 \mathrm{~mm}$. At the later stage, the dried sample was then further subjected to heat in an oven for overnight at a temperature of $100^{\circ} \mathrm{C}$. Afterward, the solid films were obtained and then further cut into $2 \mathrm{~cm}^{2} \times 3 \mathrm{~cm}^{2}$ each. The weights of the films were measured by means of a micro-balance (Santorius, Ax 224) with an accuracy of $0.001 \mathrm{mg}$. The average weights of two electrode films that make a cell was approximately $0.224 \mathrm{~g}$. Using a Perspex of about $5 \mathrm{~cm} \mathrm{x} 4 \mathrm{~cm}$, the cell was set up by sandwiching two electrodes with the electrolyte and assembled in an innovative supercapacitor tester.

XRD spectra were obtained with an XRD (Philip X'Pert XRD with $\mathrm{Cu} \mathrm{K}_{\alpha}$ radiation of wavelength $\lambda=1.54056 \AA$ for $2 \boldsymbol{\theta}$ angles between $10^{\circ}$ and $\left.80^{\circ}\right)$ that used $\mathrm{Cu} \mathrm{K} \alpha$ radiation $(\lambda=1.5406 \AA)$ operating at $40 \mathrm{kV}$ and $30 \mathrm{~mA}$. Furthermore, the surface morphologies of all firms were investigated via FESEM (SU 8030 a family member of SU 8000; Resolution capability of $1.0 \mathrm{~nm} / 15 \mathrm{kV}, 1.3 \mathrm{~nm} / 1 \mathrm{kV}$ and abling magnification of $80 \mathrm{x}$ to 2,000,000x). $\mathrm{CD}$ analysis and $\mathrm{CV}$ were respectively carried out using a newer battery charger which has been interfaced to a computer called "e-machines" (model: ET1850, Rating: 100-127/220-240 Vac, 6/3.15 A (6/3, 15 A), 60/50 Hz) and Gamry instrument Framework. The following symmetric capacitor cells were assembled;

$$
\begin{array}{rl|l|l}
\text { Ce11s: } & \text { Ce11 A - N90PVDF-HFP10 } & \text { H50 } & \text { N90PVDF-HFP10 } \\
\text { Ce11 B - N90PVDF-HFP10 } & \text { H60 } & \text { N90PVDF-HFP10 } \\
\text { Ce11 C - N90PVDF-HFP10 } & \text { H70 } & \text { N90PVDF-HFP10 }
\end{array}
$$




\section{Results and Discussions}

\subsection{Microstructure Characterizations}

The microstructure of the samples of this work was examined using XRD and FESEM. The spectra of the X-ray in these samples were obtained from an XRD; a Philip X'Pert XRD model with $\mathrm{Cu} \mathrm{K}_{\alpha}$ radiation of wavelength $\lambda=1$. $54056 \AA$ for $2 \boldsymbol{\theta}$ angles between $10^{\circ}$ and $80^{\circ}$ that used $\mathrm{Cu} \mathrm{K} \alpha$ radiation $(\lambda=1.5406 \AA)$ operating at $40 \mathrm{kV}$ and $30 \mathrm{~mA}$.

The XRD analysis of the N90PVdF-HFP10 electrode is shown in Figure 1. As seen in that figure, all diffraction peaks can be observed and the major diffraction peaks of the CPNMWCNTs can also be clearly seen. The broad diffraction peaks that appeared at $43^{\circ}$ and $56.1^{\circ}$ can be indexed to the presence of MWCNT, while an additional shapely peak at $2 \theta=26^{\circ}$ is due to the embedding of the graphitic CNTs (Wang et al., 2013b). Thus, the intensity of the peak observed, could correspond to the high concentration of the as-prepared carbon electrode (Dong et al., 2007; Hashim \& Sa'adu, 2014) of the as-prepared carbon electrode. While the first diffracted peak at the left hand side at $2 \theta=20.1^{\circ}$ correspond to crystalline peaks of PVDV (Stolarska et al., 2007). Similar XRD results were obtained by (Li et al., 2010; Stolarska et al., 2007).

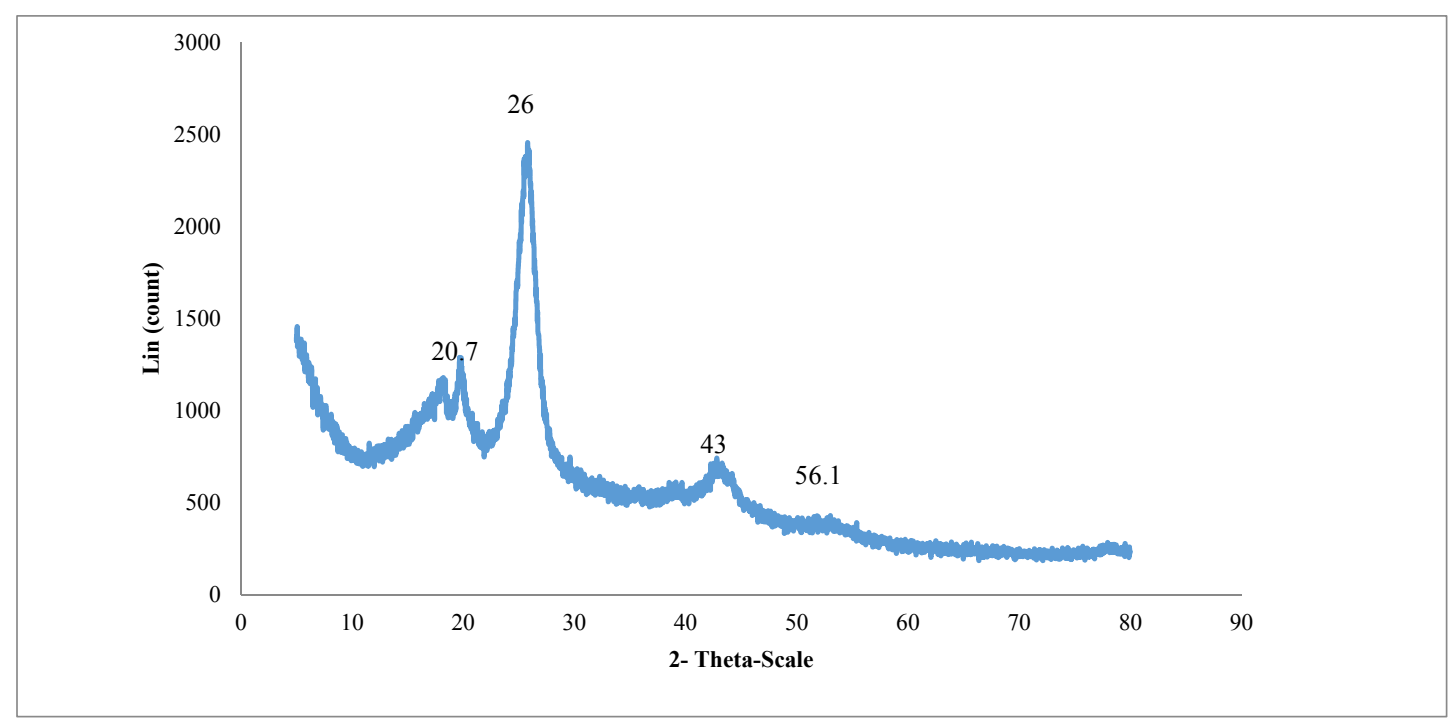

Figure 1. XRD Analysis of CPNMWCNTs

\subsection{Thermogravimetric Analysis}

Using thermal analyzer in the scale-range of $50{ }^{\circ} \mathrm{C}$ to $1000{ }^{\circ} \mathrm{C}$ under nitrogen gas $\left(\mathrm{N}_{2}\right)$ flow at a heating rate of $10^{\circ} \mathrm{C} \min ^{-1}$ on a METTLER, STAR ${ }^{\mathrm{e}} \mathrm{SW} 10.00$, the analysis of the temperature stability of the sample were investigated. We have used similar techniques in our previous work (Hashim et al., 2014). The thermal stability of the samples was discerned in Figure 2. The Figures were (a); 0 wt. \% sample (Background) (b); pure CPNMWCNTs (c) N90PVdF-HFP10 - Single scale (d); N90PVdF-HFP10 - Double scale. At first, we analyzed background heating in order clear any ruminant residue and for re-calibration. From the traces of Figure (b) it can be seen that, pure CPNMWCNTs suffered its major loss of just $3.1362 \%$ occurring at $596.56^{\circ} \mathrm{C}$ leaving a residue of $94.3867 \%$. However, when $10 \mathrm{wt}$. \% of the binder was added to the as-prepared sample, the results dramatically change, especially when compared with those of the functionalized CNTs. Figure 2 (b and c), provided the thermal stability results. In this case, the two losses were discovered. The initial loss of $4.1008 \%$ of the total samples occurs at $108.54{ }^{\circ} \mathrm{C}$, then the second and major loss was $60.1150 \%$ occurred at $745.83^{\circ} \mathrm{C}$. 

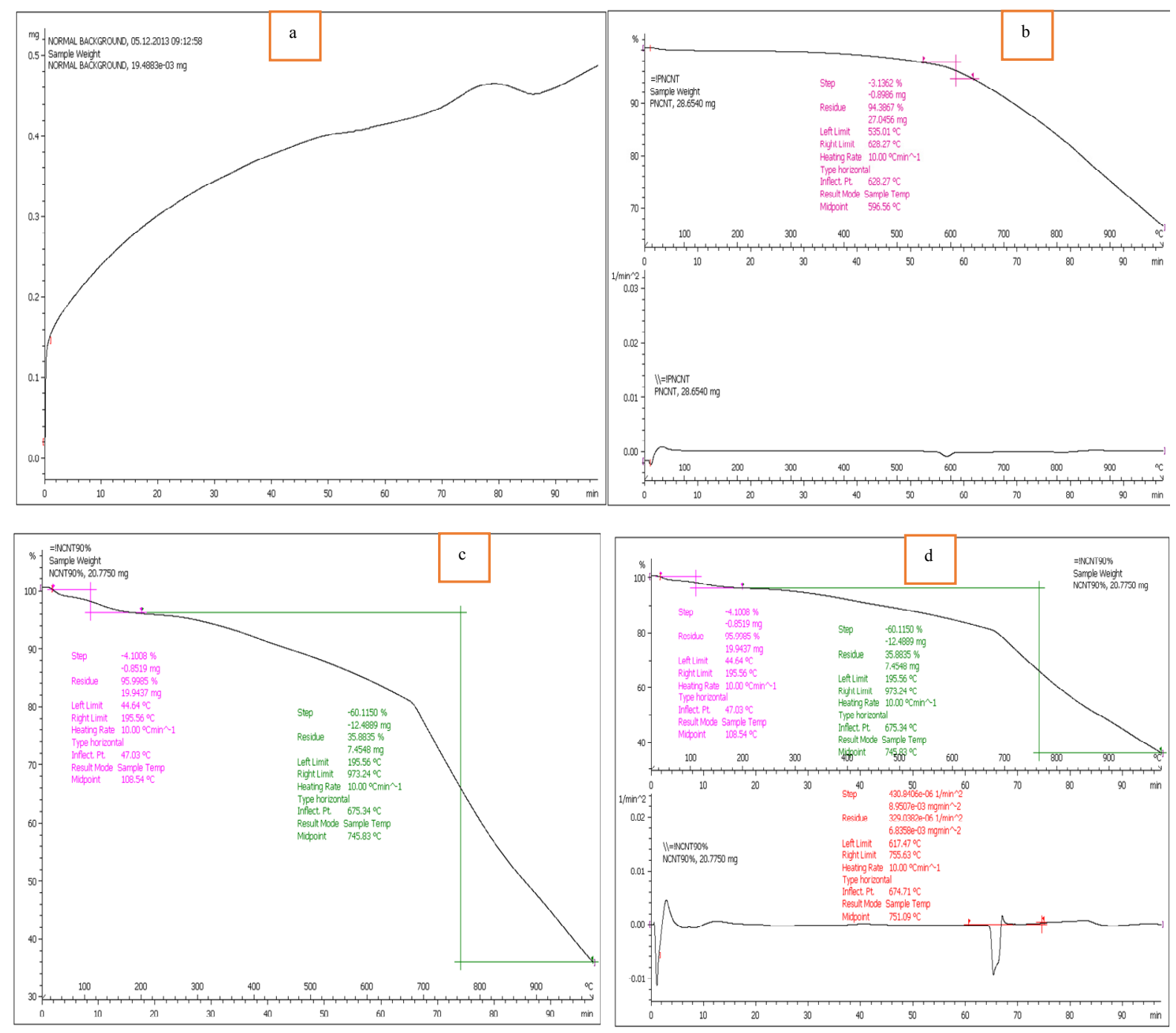

Figure 2. TGA of the electrode at (a); 0 wt. \% sample (Background) (b); pure CPNWMCNT (c) N90PVdF-HFP10 - Single scale (d); N90PVdF-HFP10 - Double scale.

\subsection{Electrochemical Behavior}

The electrochemical behaviors of CPNMWCNTs were investigated by the cyclic voltammetry (CV) and charge-discharge (CD) measurements using two-electrode system. Figure 3 reveals the CV of Cell $-\mathrm{A}$ (N90PVdF-HFP10 |H50| N90PVdF-HFP10) at scan rates of 10,50 and $100 \mathrm{mV}$, within a voltage window 0f $0.0-3.0 \mathrm{~V}$ ) and $50 \mathrm{mV}$ (for a voltage window of $1 \mathrm{~V}$ ). It can be discerned that the resulting CV curves of the cell at a scan rate of $50 \mathrm{mV}$ and within $0.0-1 \mathrm{~V}$ - voltage window, displayed leaf-like and mirror-symmetric indicating a modest ideal supercapacitive behavior for the CPNMWCNTs. The specific capacitance of the electrode materials was obtained based on the total mass of the two electrodes in the symmetric capacitor by integrating the $\mathrm{CV}$ curves in that Figure using the equation;

$$
C_{s p}=\frac{2 i}{s m}
$$

Where $i$ is the current difference, $m$ is the mass of the electrode and $s$ is the scan rate.

From the calculation, it could be obtained that, the specific capacitance is $154.1 \mathrm{Fg}^{-1}, 28.8 \mathrm{Fg}^{-1}$, and $17.7 \mathrm{Fg}^{-1}$ for scan rates of 10, 50 and $100 \mathrm{mV}$, respectively. The decrease in specific capacitance of $154.1 \mathrm{Fg}^{-1}-17.7 \mathrm{Fg}^{-1}$ is an indication of the existing relationship between capacitance and scan rate and this could either be attributed to the slow transfer of ions on the electrode electrolyte interface (Shu et al., 2013). 
Furthermore, Figure 4 displays the CV of Cell-B (N90PVdF-HFP10|H60| N90PVdF-HFP10) at scan rates of 10, 50 and $100 \mathrm{mV}$, (for a voltage window of $3 \mathrm{~V}$ ) and $50 \mathrm{mV}$ (for a voltage window of $1 \mathrm{~V}$ ). The specific capacitances obtained in this cell were $93 \mathrm{Fg}^{-1}, 36 \mathrm{Fg}^{-1}$ and $26 \mathrm{Fg}^{-1}$ for scan rates of 10,50 and $100 \mathrm{mV}$ respectively. While Figure 5 shows the CV of Cell -C (N90PVdF-HFP10 |H70| N90PVdF-HFP10) at scan rates of 10, 50 and $100 \mathrm{mV}$, (for a voltage window of $3 \mathrm{~V}$ ) and $50 \mathrm{mV}$ (for a voltage window of $1 \mathrm{~V}$ ). These results gave a balance and modest capacitance and can be considered as better than that of cells $\mathrm{A}$ and $\mathrm{B}$. The capacitance recorded here are $112.4 \mathrm{Fg}^{-1}, 40.0 \mathrm{Fg}^{-1}$ and $32.0 \mathrm{Fg}^{-1}$ for scan rates of 10,50 and $100 \mathrm{mV}$ respectively. Table 1 summarizes the results of the capacitance obtained in all the three cells and Figure 6 (a) summarizes the capacitance performance in the combined graph of capacitance against the scan rates for cells $\mathrm{A}, \mathrm{B}$ and $\mathrm{C}$.

One of the criteria in supercapacitor's fabrication and application is its ability to endure long-term cycling stability. In this respect, the cycling endurance measurement over 5000 cycles for all the cells (Figure 6 (b)) was conducted using the $\mathrm{CD}$ test at the working voltage of $1.5 \mathrm{~V}$. The figure displayed the graph of the resulting capacitance retention as a function of cycling number. Of note, compared to cells $\mathrm{A}$ and $\mathrm{B}$, cell-C (N90PVdF-HFP10 |H70| N90PVdF-HFP10) exhibits the best cycling stability with about $80 \%$ capacitance of its initial value after 5000 cycles.

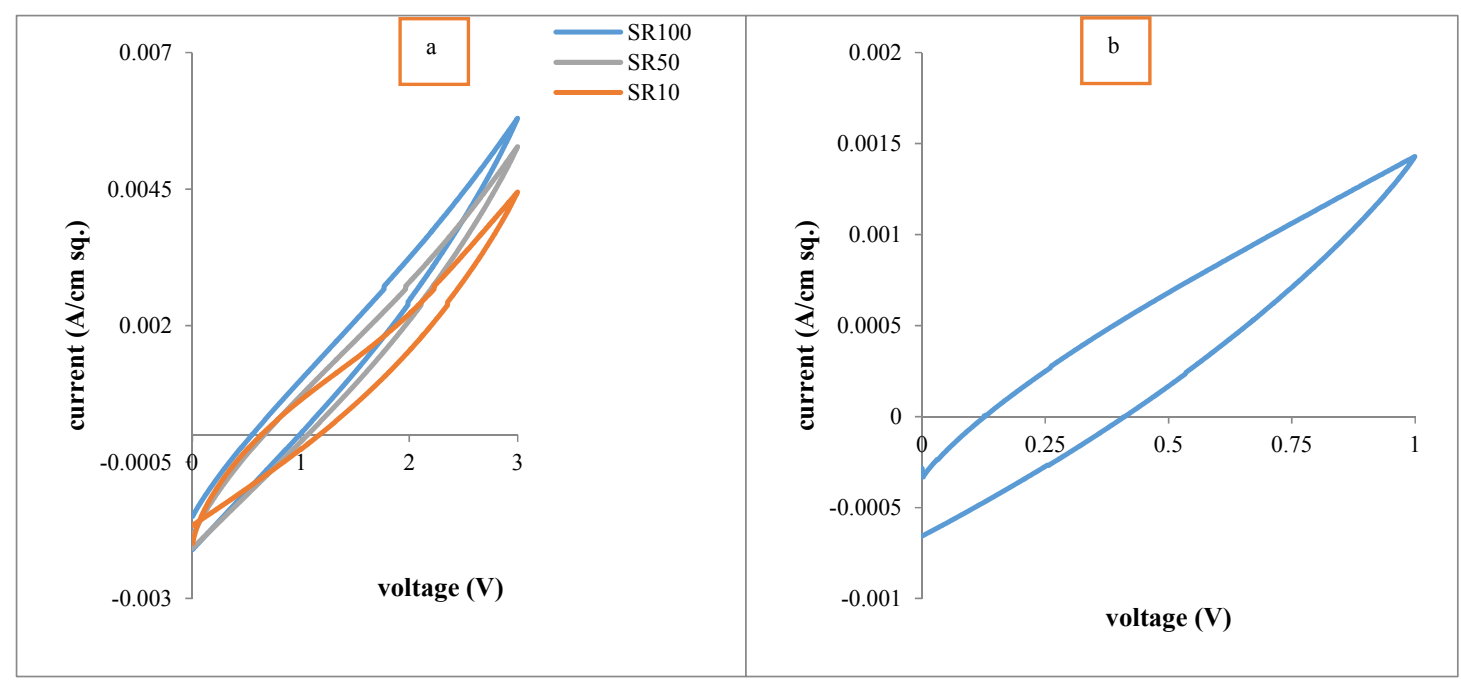

Figure 3. CV of Cell-A (N90PVdF-HFP10 |H50| N90PVdF-HFP10 at (a); scan rates of 1, 50 and 100 mV, 3 Vvoltage window (b); scan rate of $50 \mathrm{mV} ; 1 \mathrm{~V}$ - voltage window

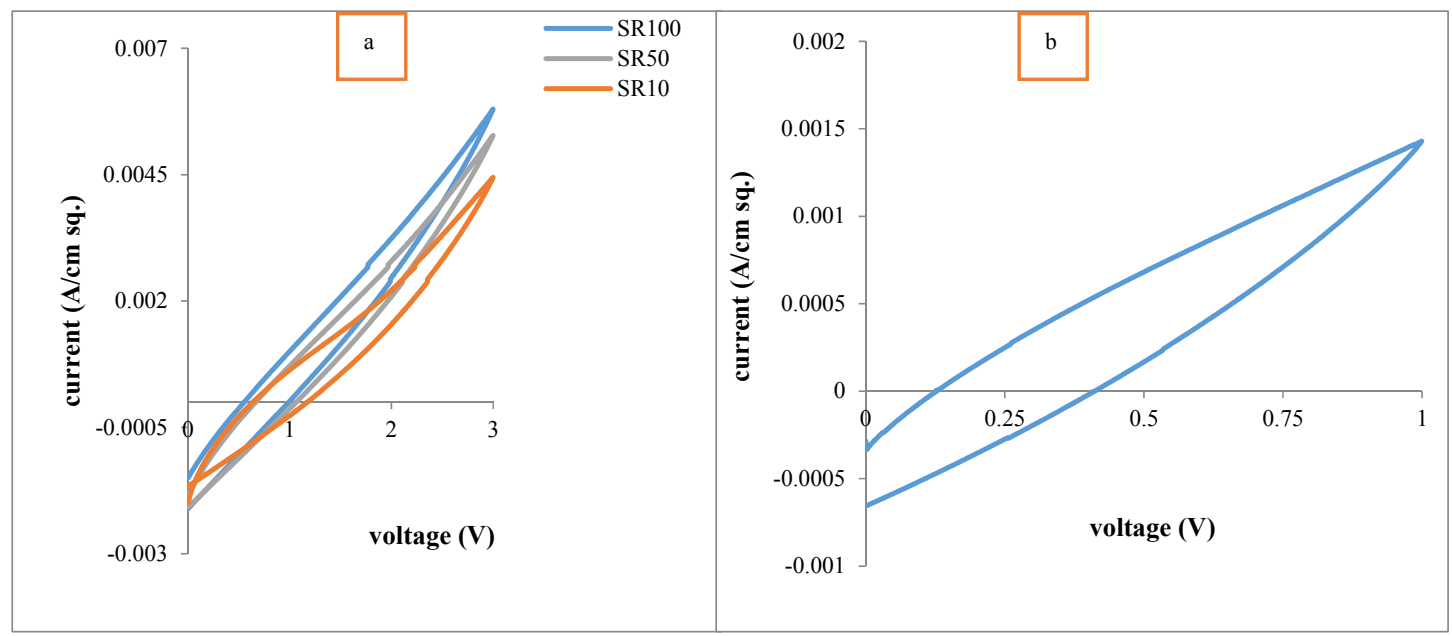

Figure 4. CV of Cell -A (N90PVdF-HFP10 |H60| N90PVdF-HFP10) at (a); scan rates of 1, 50 and $100 \mathrm{mV}, 3 \mathrm{~V}$ voltage window (b); scan rate of $50 \mathrm{mV} ; 1 \mathrm{~V}$ - voltage window 


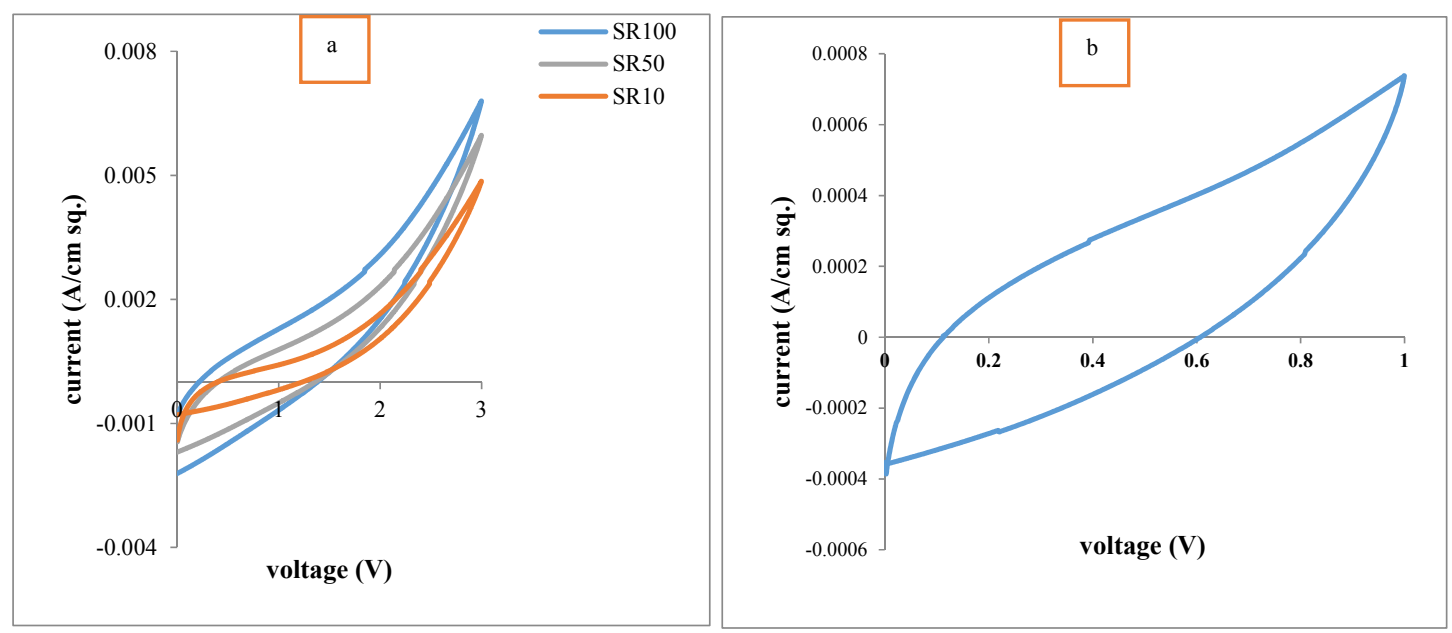

Figure 5. CV of Cell -A (N90PVdF-HFP10 |H70| N90PVdF-HFP10) at (a); scan rates of 1, 50 and $100 \mathrm{mV}, 3 \mathrm{~V}$ voltage window (b); scan rate of $50 \mathrm{mV} ; 1 \mathrm{~V}$ - voltage window

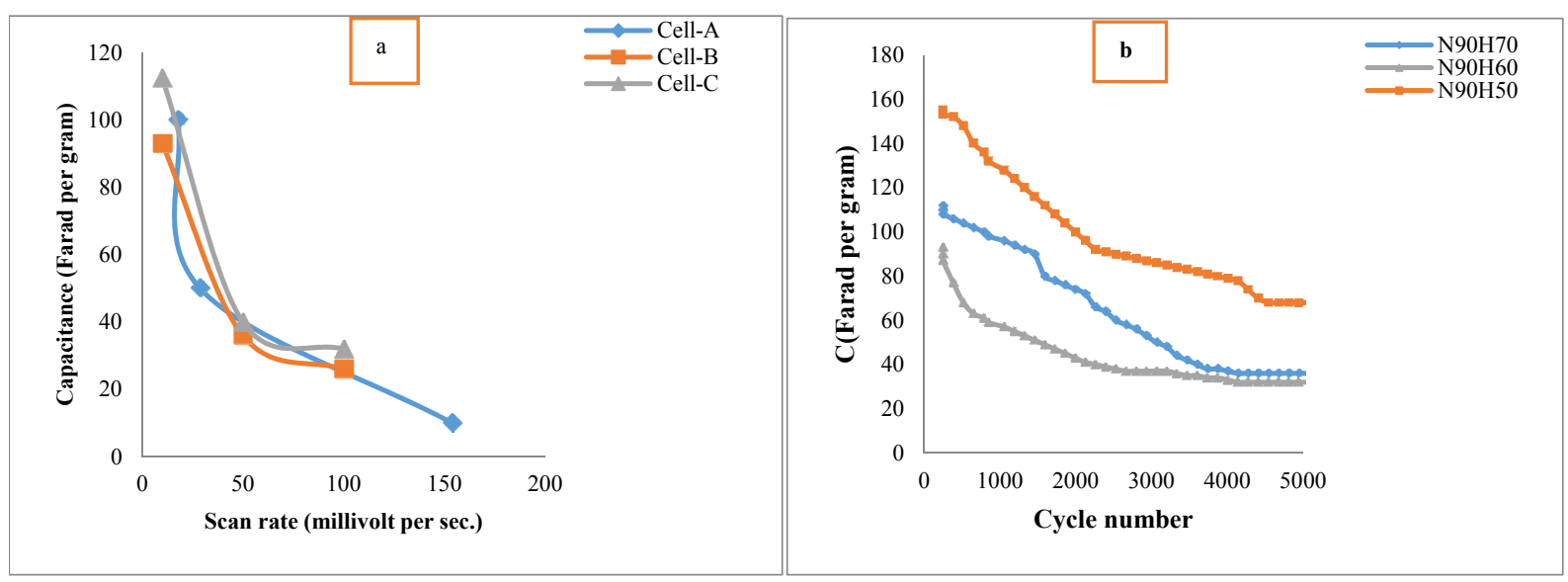

Figure 6. (a); combined graphs of capacitance against the scan rates for cells A, B and C. (b); combined cyclic performances of cells $\mathrm{A}, \mathrm{B}$ and $\mathrm{C}$

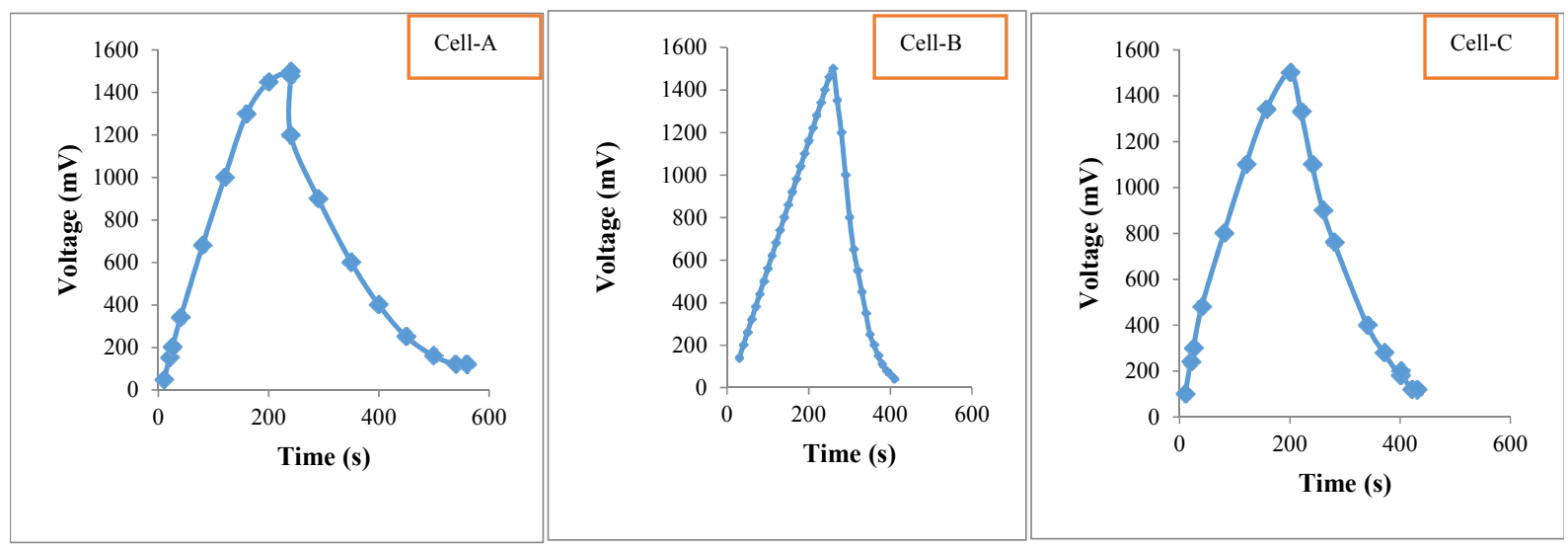

Figure 7. CD graphs of (a); Cell-A (b); Cell-B and (c); Cell- C 
Table 1. Performance of supercapacitor by the CV

\begin{tabular}{ccccc}
\hline Cells & Working voltage & \multicolumn{3}{c}{ Capacitance value of different scan rates $\left(\mathrm{Fg}^{-1}\right)$} \\
\cline { 3 - 5 } & $(\mathrm{V})$ & $100 \mathrm{mV}$ & $50 \mathrm{mV}$ & $10 \mathrm{mV}$ \\
\hline A-N90H50 & 3 & 17.7 & 28.8 & 157.1 \\
B-N90H60 & 3 & 26.0 & 36.0 & 93.0 \\
C-N90H70 & 3 & 32.0 & 40.0 & 112.4 \\
\hline
\end{tabular}

Table 2. Performance of supercapacitor by the $\mathrm{CD}$

\begin{tabular}{cccccc}
\hline Cells & $\begin{array}{c}\text { Working voltage } \\
(\mathrm{V})\end{array}$ & $\begin{array}{c}\mathrm{C}_{\mathrm{d}} \\
\left(\mathrm{Fg}^{-1}\right)\end{array}$ & $\begin{array}{c}\text { ESR } \\
\left(\Omega \mathrm{cm}^{2}\right)\end{array}$ & $\begin{array}{c}\text { Energy density } \\
\left(\mathrm{Jg}^{-1}\right)\end{array}$ & $\begin{array}{c}\text { Power density } \\
\left(\mathrm{Jg}^{-1} \mathrm{~s}^{-1}\right)\end{array}$ \\
\hline A- N90H50 & 1.5 & $16.4-163.0$ & $3.0-30.0$ & $82.0-822.0$ & $0.1-5.4$ \\
B-N90H60 & 1.5 & $8.9-89.3$ & $0.1-1.0$ & $44.7-448.4$ & $1.3-5.3$ \\
C-N90H70 & 1.5 & $14.0-139.0$ & $0.2-1.5$ & $140.0-700.0$ & $0.8-8.4$ \\
\hline
\end{tabular}

Galvanostatic CD is considered one of the complimentary procedure of recording CD relatives at constant-current that is normally employed to practically test supercapacitors and batteries. In a theoretical sense, for a constant capacitor device with less effect on high internal resistance, the constant-current charge and discharge relations are straight lines with $+1 / \mathrm{c}$ and $-1 / \mathrm{c}$ respectively (Niu et al., 2006). In view of the above, the capacitance, power and energy densities were also investigated using the galvanostatic CD test. In Figure 7, the CD graphs of (a); Cell-A (b); Cell-B and (c); Cell- $\mathrm{C}$ were all depicted at a working voltage of $1.5 \mathrm{~V}$ and at three different current densities i.e. 10, 20 and $100 \mathrm{~mA}$. The effective capacitance, power and energy densities were also calculated. In cell-A, the discharged capacitances obtained were $16.36 \mathrm{Fg}^{-1}, 32.73 \mathrm{Fg}^{-1}$ and $163.66 \mathrm{Fg}^{-1}$ respectively at an applied current density of 100, 20 and $10 \mathrm{~mA}$; the calculated energy and power densities are $82.21 \mathrm{Jg}^{-1} / 1.27 \mathrm{Jg}^{-1} \mathrm{~s}^{-1}, 164.40$ $\mathrm{Jg}^{-1} / 2.52 \mathrm{Jg}^{-1} \mathrm{~s}^{-1}$ and $822.00 \mathrm{Jg}^{-1} / 5.38 \mathrm{Jg}^{-1} \mathrm{~s}^{-1}$ at the aforementioned current densities. For the cell- $\mathrm{B}$, the discharged capacitances obtained were $8.89 \mathrm{Fg}^{-1}, 17.80 \mathrm{Fg}^{-1}$ and $89.28 \mathrm{Fg}^{-1}$ respectively at an applied current density of 100, 20 and $10 \mathrm{~mA}$; the calculated energy and power densities are $44.70 \mathrm{Jg}^{-1} / 1.26 \mathrm{Jg}^{-1} \mathrm{~s}^{-1}, 89.40$ $\mathrm{Jg}^{-1} / 2.52 \mathrm{Jg}^{-1} \mathrm{~s}^{-1}$ and $448.40 \mathrm{Jg}^{-1} / 12.55 \mathrm{Jg}^{-1} \mathrm{~s}^{-1}$ at the said current densities. Finally, the resulting discharge capacitance of the cell-C are; $13.95 \mathrm{Fg}^{-1}, 27.90 \mathrm{Fg}^{-1}$ and $139.50 \mathrm{Fg}^{-1}$ respectively at an applied current density of 100,20 and $10 \mathrm{~mA}$; power/energy densities are $70.06 \mathrm{Jg}^{-1} / 0.84 \mathrm{Jg}^{-1} \mathrm{~s}^{-1}, 140.12 \mathrm{Jg}^{-1} / 1.67 \mathrm{Jg}^{-1} \mathrm{~s}^{-1}$ and 700.16 $\mathrm{Jg}^{-1} / 8.37 \mathrm{Jg}^{-1} \mathrm{~s}^{-1}$ at the aforementioned current densities. Normally, the dwindle in capacitance could be as a result of the dissolution of the active materials in the electrolytes, mechanical faults of the electrode (e.g. Expansion, agglomeration and so on) and the imbalance of the two electrodes which can cause instability of the electrode potential (Wang et al., 2013). Hence, the discharged capacitance decreases with the increase in current density, which could be as a result of the low penetration of ions into the inner region of the pores due to fast potential changes.

\section{Conclusion}

We demonstrated a novel of a high-performance symmetric supercapacitor based on CPNMWCNTs sandwiched with the hybrid solid polymer electrolyte. Of the three cells assembled, the optimized N90PVdF-HFP10 |H50| N90PVdF-HFP10 (cell A) symmetric supercapacitor stands better to be operated reversibly in a wide potential window as high as $3.0 \mathrm{~V}$ and delivers a high capacitance, energy and power densities of $163.66 \mathrm{Fg}^{-1}, 822.00 \mathrm{Jg}^{-1}$ and $5.38 \mathrm{Jg}^{-1} \mathrm{~s}^{-1}$ respectively, and long-term cycling stability of 5000 cycles. With the increasing demands on energy storage systems with high energy and power densities, therefore, these results afford a convenient and efficient way to construct supercapacitors based on CPNMWCNTs electrode materials.

\section{Acknowledgements}

The authors wish to extend their gratitude and appreciations to the management of the Faculty of Science and Technology USIM under which ERGS grant (USIM/ERGS-FST-52-50111) has been provided for the purpose of this research. 


\section{Reference}

Bittner, A. M., Zhu, M., Yang, Y., Waibel, H. F., Konuma, M., Starke, U., \& Weber, C. J. (2012). Ageing of Electrochemical Double Layer Capacitors. Journal of Power Sources, 203, 262-273. http://dx.doi.org/10. 1016/j.jpowsour.2011.10.083

Dong, B., He, B., Xu, C., \& Li, H. (2007). Preparation And Electrochemical Characterization Of Polyaniline/Multi-Walled Carbon Nanotubes Composites For Supercapacitor. Material Sci. and Engineering, 143, 7-13. http//dx.doi.org/ 10.1016/j.mseb.2007.06.017

Dubal, D. P., \& Rudolf, H. (2013). All-Solid-State Flexible Thin Film Supercapacitor Based On $\mathrm{Mn}_{3} \mathrm{O}_{4}$ Stacked Nanosheets with Gel Electrolyte. Energy, 51, 407-412. http://dx.doi.org/10.1016/j.energy.2012.11.021

Hashim, M. A, \& Sa'adu, L. (2014). Design, Fabrication and Characterization of a Commercially Prepared Carboxyl Multiwalled Carbon Nanotubes With a Hybrid Polymer Electrolytes. Applied Physics Research, 6, 106-118. http://dx.doi.org/10.5539/apr.v6n4p106

Hashim, M. A, Sa'adu, L., \& Dasuki, A. K. (2012). Supercapacitor Based On Activated Carbon And Polymer Electrolyte. International Journal Of Sustainable Energy And Environmental Research, 1, 1-6.

Hashim, M. A, Sa'adu, L., Baharuddin, M., \& Dasuki, A. K. (2014). Using PVA, Methacrylate and Lauroyl Chitosan as Separator in Supercapacitors. Journal of Materials Science Research, 3, 25-29. http://dx.doi.org/10.5539/jmsr.v3n1p25

Li, Q., Li, Z., Lin, L., Wang, X.Y., Wang, Y., Zhang, C., \& Wang, H. (2010). Facile Synthesis of Activated Carbon/Carbon Nanotubes Compound For Supercapacitor Application. Chemical Engineering Journal, 156, 500-504. http//dx.doi.org/ 10.1016/j.cej.2009.10.025

Li, X., \& Wei, B. Q. (2013). Supercapacitors Based on Nanostructured Carbon. Nano Energy, 2, 159-173. http://dx.doi.org/10.1016/j.nanoen.2012.09.008

Lim, D. H., Manuel, J., Ahn, J. H., Kim, J. K., Jacobsson, P., Matic, A., ... Kim, K. W. (2012). Polymer Electrolytes Based on Poly(Vinylidene Fluoride-Co-Hexafluoropropylene) Nanofibrous Membranes Containing Polymer Plasticizers for Lithium Batteries. Solid State Ionics, 225, 631-635.

Niu, J., Pell, W. G., \& Conway, B. E. (2006). Requirements for Performance Characterization of C Double-Layer Supercapacitors: Applications to a High Specific-Area C-Cloth Material. Journal of Power Sources, 156, 725-740. http://dx.doi.org/10.1016/j.jpowsour.2005.06.002

Sa'adu, L., Hashim, M. A., \& Baharuddin, M. (2014). A Novel Conductivity Studies and Characterizations of PVA-Orthophosphoric-Filter paper Electrolytes. Journal of Materials Science Research, 3, 1-12. http://dx.doi.org/10.5539/jmsr.v3n4p1

Sa'adu, L., Hashim, M. A., \& Baharuddin, M. (2014). Conductivity Studies and Characterizations of PVA-Orthophosphoric Electrolytes. Journal of Materials Science Research, 3, 48-58. http://dx.doi.org/10.5539/jmsr.v3n3p48

Shi, S., Xu, C., Yang, C., Li, J., Du, H., Li, B., \& Feiyu, K. (2013). Flexible Supercapacitors. Particuology, 11, 371-377. http//dx.doi.org/10.1016/S0378-7753(01)00938-7

Shu, D., Lv, C., Cheng, F., He, C., Yang, K., Nan, J., \& Long, L. (2013). Enhanced Capacitance and Rate Capability of Nanocrystalline VN as Electrode Materials for Supercapacitors . Int. J. Electrochem. Sci., 8, $1209-1225$.

Snook, G. A., Kao, P., \& Adam, S. (2011). Best, Conducting-Polymer-Based Supercapacitor Devices and Electrodes. Journal of Power Sources, 196, 1-12. http//dx.doi.org/ 10.1016/j.jpowsour.2010.06.084

Stepniak, I., \& Ciszewski, A. (2010). New Design of Electric Double Layer Capacitors with Aqueous Lioh Electrolyte as Alternative to Capacitor with KOH Solution. Journal of Power Sources, 195, 2564-2569. http://dx.doi.org/10.1016/j.jpowsour.2009.10.094

Stolarska, M., Niedzicki, L., Borkowska, R., Zalewska, A., \& Wieczorek, W. (2007). Structure, transport properties and interfacial stability of $\mathrm{PVdF} / \mathrm{HFP}$ electrolytes containing modified inorganic filler. Electrochimica Acta, 53, 1512-1517.

Wang, A., Yang, Y., Huang, Z., \& Kang, F. (2013). A high-performance asymmetric supercapacitor based on carbon and carbon-MnO2 nanofiber electrodes. Carbon, 61, 190-199. http://dx.doi.org/10.1016/j.carbon. 2013.04.084. 
Wang, H., Li, Z., Tak, J. K., Holt, C. M. B., Tan, X., Xu, Z., ... David, M. (2013). Supercapacitors Based on Carbons with Tuned Porosity Derived from Paper Pulp Mill Sludge Biowaste. Carbon, 57, $317-328$. http//dx.doi.org/ 10.1016/j.carbon.2013.01.079

Wu, Y., Zhang, T., Zhang, F., Wang, Y., Ma, Y., Huang, Y., ... Yongsheng, C. (2012). In Situ Synthesis of Graphene/Single-walled Carbon Nanotube Hybrid Material by Arc-Discharge and Its Application in Supercapacitors. Nano Energy, 1, 820-827. http//dx.doi.org/ 10.1016/j.nanoen.2012.07.001

\section{Copyrights}

Copyright for this article is retained by the author(s), with first publication rights granted to the journal.

This is an open-access article distributed under the terms and conditions of the Creative Commons Attribution license (http://creativecommons.org/licenses/by/3.0/). 